Jambura Journal of Educational Management

Volume 1 Nomor 1 Maret 2020, halaman 27-40

\title{
Pengendalian Tingkah Laku Siswa Melalui Pendekatan Manajemen Kelas
}

\author{
Isnanto $^{1}$, Asni Ilham², Nurhatima Lakita ${ }^{3}$ \\ Jurusan Pendidikan Guru Sekolah Dasar Fakultas Ilmu Pendidikan \\ Universitas Negeri Gorontalo \\ E-mail: isnanto@ung.ac.id
}

\begin{abstract}
INFO ARTIKEL
ABSTRAK

Sejarah Artikel:

Diterima: Januari 2020

Disetujui: Februari 2020

Dipublikasi: Maret 2020

\section{Kata kunci:}

Tingkahlaku; siswa; manajemen kelas

Keywords:

Behavior; students; class management

Tujuan penelitian untuk mengetahui: (1) Peran guru dalam manajemen kelas; (2) Tingkah laku dalam kelas; dan (3) Penyelesaian masalah dalam manajemen kelas; (4) Kerjasama orang tua dan guru dalam mengendalikan tingkah laku siswa di kelas. Jenis penelitian ini penelitian kualitatif dengan menggunakan pendekatan studi kasus. Berdsarkan hasil dan pembahasan penelitian dapat disimpulkan, bahwa pengendalian tingkah laku siswa dapat diatasi dengan berbagai cara antara lain: (a) Guru sebagai motivator dan pemberi nasehat, sebagai pembimbingan, melalui penjadwalan piket, pemberian hukuman yang mendidik, serta penguasaan materi terhadap siswa; (b) Pendekatan yang sering guru gunakan di kelas yaitu pendekatan otoriter, pengajaraan, pengubahaan tingkah laku, sosio-emosional, kerja kelompok, elektis atau pluralistik, maupun teknologi informasi; (c) Kerja sama antara guru dan orang tua. Dalam hal ini guru lebih menekankan pada potensi siswa serta cara bertingkah laku yang baik, serta menerapkan kreatifitas dan inisiatif guru dalam pembelajaran.
\end{abstract}

\section{ABSTRACT}

The research objectives are to find out: (1) The role of the teacher in classroom management; (2) classroom behavior; and (3) Settlement of problems in class management; (4) The cooperation of parents and teachers in controlling student behavior in class. This type of research is qualitative research using a case study approach. Based on the results and discussion of the study it can be concluded, that the control of student behavior can be overcome in various ways including: (a) The teacher as a motivator and adviser, as guidance, through scheduling pickets, giving penalties that educate, and mastery of the material to students; (b) The approaches that teachers often use in class are auteriter, teaching, behavior change, socioemotional, group work, electronic or pluralistic, and information technology; (c) Cooperation between teachers and parents. In this case the teacher emphasizes more on the potential of students and how to behave properly, as well as applying the creativity and initiative of the teacher in learning.

(C) 2020 Isnanto, Asni Ilham, Nurhatima Lakita Under The License CC BY-SA 4.0 


\section{PENDAHULUAN}

Tingkah laku peserta didik merupakan suatu hal yang bersifat individu. Mereka menonjolkan sifat yang personal dalam menghadapi kehidupan. Bagaimana seorang peserta didik mengalami paksaan juga bergantung kepada perkembangannya dan juga kepribadiannya, seberapa lama dan intensitas dari paksaan itu juga merupakan sebuah faktor, hilang kepercayaan yang total, perasaan bersalah, malu, takut, dan menarik diri. (Hakim, 2012:82). Hal ini senada dengan apa yang dikatakan oleh Fhilip Graham dalam (Okvianti, 2016) perilaku anak dapat dipengaruhi faktor pribadi maupun lingkungan. Seperti pendapat, faktor pribadi yaitu faktor yang terdapat dalam diri seseorang yang merupakan bawaan lahir. Misal faktor bakat yang mempengaruhi temperamen dan ketidak mampuan seseorang dalam menyesuaikan diri.

Efektif terhadap perilaku siswa melalui penggunaan teknik pengelolaan kelas (Suwardi dan Daryanto, 2017: 155). Disamping berkitan dengan siswa, pengelolaan kelas juga erat kaitanya dengan penganturan lingkungan fisik kelas. Guru perlu memperhatikan bagaimana penataan ruang kelas yang ideal meliputi visibility (keleluasaan pandangan), accesibility (mudah dicapai), fleksibillity (keluwesan), kenyamanan, dan keindahan.Tingkah laku siswa merupakan kegiatan yang aktif dilakukan oleh individu baik yang dilihat langsung, maupun yang tidak dilihat langsung. Sedangkan Menurut Skinner seperti yang dikutip oleh Noto Atmodjo perilaku merupakan respon atau reaksi seseorang terhadap stimulus atau rangsangan dari luar. Oleh karena perilaku ini terjadi melalui proses adanya stimulus terhadap organisme, dan kemudian organisme ini merespons (Idhami,2012-65).

Perilaku normal merupakan perilaku yang dapat diterimah oleh manusia pada umumnya sedangkan perilaku abnormal merupakan perilaku yang tidak dapat diteriah oleh manusi atau perilku menyimpang, dan tidak sesuai dengan kaidah-kaidah ataau norma-norma manusia. Perilaku abnormal juga disebut perilaku menyimpang karena perilaku ini perilaku yang tidak disenangi oleh manusia. Tingkah laku merupakan kegiatan manusia yang dilakukan baik secara positif maupun secara negative. Jadi sikap dan perilaku memiliki hubungan berbanding lurus, dimana sikap seseorang dalam menanggapi sesuatu akan berpengaruh pada perilaku yang dihasilkan. Perilaku positif atau negatif dari seorang siswa dapat ditelusuri berdasarkan sikap yang mendasari perilaku tersebut (Idhami 2012:77).

Menurut Pandangan permisive yang memutuskan perhatian pada usaha, dikemukakan tiga pandangan mengenai pendekatan dalam pengelolaan kelas, yaitu: 
Pendekatan perubahan tingkah laku (Behavior Modification Approach), Pendekatan penciptaan iklim Sosio-emosional (Socio Emosional Climate Approach)(Azzet, 2011:32).Pendekatan proses kelompok (Group Processes Approach). Pendekatan elektif (Elektif Approach)(Yamin Dan Musah, 2009:65).Selain empat pendekatan manajemen kelas yang di atas masih ada beberapa pendekatan seperti pendekatan kekuasaan (otoriter), Pendekatan ancaman (intimidasi), Pendekatan kebebasan, Pendektan pengajaran, Pendekatan perubahan tingkah laku, Pendekatan sosio-emosional, Pendekatan kerja kelompok, Pendekatan elektif atau pluralistik, Pendekatan teknologi dan informasi (Karwati dan Priansa, 2014: 11-15).

Namun, berdasarkan observasi awal yang lakukan pada bulan Desember 2018 di SDN 20 Dungingi Kota Gorontalo, pada kenyataanya di mana pengelolaan kelas masih menjadi salah satu masalah yang sulit diselesaikan oleh guru. Beberapa kendala yang menyebabkan terhambatnya pengelolaan kelas yang efektif dalam proses pembelajaran berlangsung; (1) tugas guru yang multidimensi yang menuntut berbagai tugas sekaligus sehingga membuat guru kesulitan dalam melakukan pengelolaan kelas dan untuk menjalankan tugasnya berkaitan dengan hal-hal yang bersifat administratif, seperti menyusun rencana pembelajaran dan lain sebagainya; (2) proses belajar mengajar di dalam kelas yang dibatasi waktu, sehingga menuntut guru untuk berpikir dan bertindak cepat. Namun hal ini tidak cukup memaksimalkankegiatan guru karena masih akan dibatasi oleh waktu istirahat dan kegitan-kegiatan lainya yang menyebabkan kegitan pengelolaan kelas menjadi di kesampingkan.

Adapun jumlah siswa kelas IV berjumlah 33 orang, laki-laki 23 orang dan perempuan 10 orang, di kelas ini peneliti menemukan secaraa langsung dan juga bertanya kepada wali kelas IV terdapat perilaku kenakalan siswa di kelas IV. Kenakalan siswa itu dijumpai pada saat peneliti mengamati proses pemebelajaran yang sedang berlangsung di kelas IV, seperti: mendorong teman pada saat proses pembelajaaraan berlangsung, berbicara dengan teman sembangkunya, tidak mengerjakan tugas, menyontek hasil kerja temanya. melakukan kejailan pada teman sekalasnya, berkelahi, dan mengejek temanya.

Berdasarkan hasil wawancara dengan guru perwalian kelas IV SDN 20 Dungingi Kota Gorontalo pada Tanggal 10 Desember 2018 mengatakan bahawa memang terdapat tingkah laku yang menyimpang siswa seperti: ada siswa yang menyembunyikan buku temanya, siswa yang menggangu temanya (mengejek, mengambil barang temanya tanpa izin).Berdasarkan hasil observasi awal dan kajian literatur maka rumusan masalah dari penelitian ini yaitu untuk mengetahui: (1) Bagaimana peran guru dalam manajemen kelas; 
(2) Bagaimana tingkah laku dalam kelas; dan (3) Bagaimana penyelesaian masalah dalam manajemen kelas; (4) Bagaimana Kerjasama orang tua dan guru dalam mengendalikan tingkah laku siswa di kelas.

Dengan adanya masalah yang telah diungkapan tersebut peneliti berharap bahwa semua masalah yang terjadi pada siswa dapat ditangani dengan baik dengan berupaya semaksimal mungkin guru agar nantinya tingkah laku siswa menuju kearah yang lebih baik dan menjadi teladan bagi orang disekitarnya. Seorang guru harus benar-benar mampu menjelaskan kepada siswa cara bertingkah laku yang sebenarnya. Karena mendidik merupakan kegiatan pengajaran kepada siswa, dengan pengajaraan yang diberikan guru, ia mampu mengembangkan potensi dirinya dengan menerapakan sesuatu yang telah dipelajari. Seorang guru harus memberikan kesempatan kepada siswa untuk menarapkan tingkah laku yang baik dan benar karena guru merupakan orang tua kedua dari orang tua di rumah. Jadi seorang guru merupakan teladan bagi siswa-siswanya.

Bukanlah hal yang mudah mengubah tingkah laku siswa menjadi lebih baik, dibutuhkan pendekatan kepada siswa agar ia bisa menjadi lebih baik untuk merubah tingkah lakunya. Bukan hanya guru saja yang berperan penting untuk mengubah tingkah lakunya menjadi lebih baik tetapi kedua orang tuanya juga harus membantu guru merubah tingkah laku siswa tersebut. Tujuan penelitian untuk mengetahui: (1) Peran guru dalam manajemen kelas; (2) Tingkah laku dalam kelas; dan (3) Penyelesaian masalah dalam manajemen kelas; (4) Kerjasama orang tua dan guru dalam mengendalikan tingkah laku siswa di kelas

\section{METODE PENELITIAN}

Peneliti ini dilakukan di SDN 20 Dungingi Kota Gorontalo, Jalan Rambutan, Desa Huangobotu, Kecamatan Dungingi, Kota Gorontalo. Pendekatan penelitian yaitu pendekatan studi kasus.Sumber data dalam penelitian kualitatif ini merupakan subjek dari mana data tersebut dapat diperoleh.

Data yang diambil dalam penelitian ini adalah data yang diperoleh dari hasil observasi partisipan, wawancara secara mendalaam terhadap informan, dengan sumber data wali kelas IV, siswa kelas IV, kepala sekolah dan orang tua siswa kelas IV. Serta beberapa sumber data sekuner yang dapat dijadikan sebagai data pendukung antara lain buku sebagai acuan referensi, jurnaal hasil penelitian, skripsi, doumentasi atau arsip sekolah. Dalam penelitian ini peneliti, untuk memperoleh data mengenai teknik penelitian penggumpulan data yang utama dalam penelitian kualitatif berupa observasi wawancara, 
dan dokumentasi. Analisis data dilakukan melalui reduksi data, penyajian data, serta penarikan kesimpulan.Untuk pengecekan keabsahan data dilakukan melalui triangulasi, analisis kasus negatif, menggunakan bahan referensi, serta member check.

\section{HASIL PENELITIAN}

\section{Peran Guru dalam Manajemen Kelas}

Berdasarkan penelitian yang telah dilakukan proses belajar mengajar guru sudah menerapkan proses pengelolaan kelas dengan baik, dintaranya guru harus tauh bagaimana karakteristik setiap siswa yang ada di dalam kelas, membimbing dan memudahkan belajar siswaa serta mengatur dan mengrahkan kegiatan belajar. Dalam pengelolaan pembelajaran manajemen kelas guru telah menjalankan tugasnya dengan baik bukan hanya sebagai pendidik saja tetapi sebagai motivator dan nasehat, bagai pembimbingan, melalui penjadwalan piket, pemberian hukuman yang mendidik, serta penguasaan materi terhadap siswa.

\section{Tingkah Laku dalam Kelas}

Dari hasil penelitian ditemukan beberapa hambatan dalam dunia pendidikan baik yang dipengaruhi oleh guru, siswa, serta lingkungan sosio-emosional siswa. Seperti ketika guru berhalangan hadir karena masalah pribadi, maupun dalam hal tugas administrasi. Ditambah lagi dengan berbagai kegiatan yang harus dilakukan guru secara bersamaan di dalam kelas. Yang mana tugas dari seorang guru antara lain mengajar, mengarahkan mendidik, menilai dan mengevaluasi siswa, hal ini merupakan peran penting seorang guru dalam melakukan proses pembelajaran. Bukan hanya tugas yang bersangkutan dengan pihak sekolah saja tetapi ada tugas pribadi guru yang tidak bisa ditinggalkan sehinga mengakibatkan proses pembelajaran menjadi tertuda.

Bukan hanya guru saja yang mengalami terjadinya hambatan dalam melakukan proses pembelajaran tetapi siswa juga dimana siswa terlihat sering menimbulkan masalah didalam kelas, perilaku yang kurang tertib pada saat proses pembelajaraan dan ada sebagian siswa mengganggu temannya sehigga terjadinya hambatan dalam belajar. Serta melakukan pelangaran pada aturaan yang sudah ditetapkan oleh guru.

\section{Penyelesaian Masalah dalam Manajemen Kelas}

Pendekaatan yang digunakan dalam penyelsaian masalah dalam manjemen kelas di SDN 20 Dungingi bermacam-macam. Dari hasil menelitian pendekataan yang sering digunakan guru antara lain pendekatan otoriter, pengajaraan, pengubahaan tingkah laku, sosio-emosional, kerja kelompok, elektis atau pluralisstik, maupun teknologi informasi. 
Pendektan tersebut sangat ditonjolkaan dalam melakukaan proses pembelajaran, guru sering kali menggunakn penekatanini dalam waktu bersamaan, bahkan guru lebih dari saatu pendekatan ssekaligus dalam mengatasi masalah yang muncul dalam proses pembelaajaran.

4. Kerjasama Orang Tua dan Guru dalam Mengendalikan Tingkah Laku Siswa

Berdasarkan hasil penelitian yang peneliti temukan di SDN 20 Dungingi bahwa guru telah mampu melakukan kegiatan pembelajaran dengan menggunakan beberapa pendekatan manajemen kelas guru juga dapat menentukan manakah pendekatan yang tepat digunakan dalam menyelesaikan setiap masalah yang timbul dalam proses manajerial kelas.

\section{PEMBAHASAN}

1. Peran Guru dalam Manajemen Kelas

Dalam pengelolaan pembelajaran manajemen kelas guru telah menjalankan tugasnya dengan baik bukan hanya sebagai pendidik saja tetapi sebagai motivator dan nasehat, bagai pembimbingan, melalui penjadwalan piket, pemberian hukuman yang mendidik, serta penguasaan materi terhadap siswa.

Mengembangkan motivasi belajar siswa merupakan salah satu strategi yang harus dilakukan guru dalam memaksimalkan pengelaan manajemen kelas. Guru dalam hal ini telah berupaya maksimal dalam melakukan tugasnya sebagai pengejar, dimana guru lebih perduli dalam menggunakan kalimat ketika merespon setiap perilaku yang ditunjukan siswa karena guru menyadari bahwa setiap siswa memiliki karakteristik yang berbeda. Pemberihan nasehat-nasehat kepada siswa tidak lepas dari bagaimana komunikasi yang lebih terjalin antara guru dengan siswa di kelas IV yang telah berjalan cukup baik. Hal ini ditandai dengan berbagai upaya yang dilakukan guru dalam membangkitkan semangat siswa terhadap materi pembelajaran maupun sikap bertingkah laku siswa melalui dengan memberihan nasehat dan motovasi kepada siswa yang menunjukan sikap tingkah laku yang positif selama berada di dalam kelas.

Dilain pihak pihak guru berupaya mengembangkan hubungan yang positif pada siswa dengan melayani siswa dengan sebaik mungkin, memberikan perhatian pada siswa, serta mengadakan variasi dengan mengajak siswa bermain sambil belajar ketika siswa merasa bosan dan jenuh ketika pembelajaran berlangsung. Sebagai seorang guru harus menunjukan bahwa dirinya mampu menciptakan suasana belajar yang hangat dan meyenangkan serta membangkitkan semangat belajar siswa tidak lupa pula menanamkan 
kepercayaan diri siswa dengan memberikan kesempatan yang sama bagi siswa setiap siswa mengemukakan pendapatnya dan lebih memberikan semangat keberanian siswa dibanding dengan benar tidaknya pendapat yang diutarakan siswa saat proses pembelajaran. Dengan adanya komunikasi seperti ini sangat membantuh keberanian siswa dalam mengemukakan pendapatnya ketika siswa berani maju dan berhasil mengemukakan pendapatnya guru memberikan tepuk tangan mupun nasehat sebagai bentuk apresiasi guru kepada siswa yang berani melakukan hal tersebut. Sebagaimana pendapat yang dikemukakan oleh Wiliam James (Usman, 2011;32) pembelajran yang efektif merupakan faktor yang menentukan keterlibatan siswa secara aktif dalam proses pembelajaran.

Sebagai seorang guru, guru harus memahami bahwa belajar merupakan suatu usaha mencari dan menemukan suatu makna. Dengan hal ini, guru harus membantu siswa agar mampu memahami dan bertindak sesuai dengan hakikat belajar tersebut. Setiap apa yang dialami oleh siswa dalam proses pembelajaran tentu saangat erat kaitanya dengan peran guru sebagai pembimbing. Setiap siswa pasti memiliki karakteristik yang berbeda guru sabagai pembimbing harus mengarahkaan siswa berpikir lebih dewasa dan siswa tersebut merupakan tanggung jawab guru dan haus membuhtuhkan perhatian khusus baik dalam aspek emosional dan intelegensi siswa.

Sebagai manajer guru bertanggung jawab memelihara lingkungan fisik kelasnya agar senantiasa menyenangkan untuk belajar dan mengarahkan atau membimbing prosesproses intelektual dan sosial di dalam kelas. Dengan demikian guru tidak hanya belajar saja, tetapi juga menggembangkan kebiasaan bertingkah laku yang baik, dan belajar secarah efektif di kalangan siswa (Usman, 2011-10). Oleh karenanya proses pembelajaran yang efektif tidak cukup hanya menyedikan metode dan media pemebelajaran saja tetapi guru harus memahami karakteristik siswa, guru harus tau perbedaan-perbedaan individual dalam banyak segi dan bidang diantaranya, perbedaan dalam intelegensi, kemampuan dalam kognitif dan bahasa, perkembangan kepribadaian dan perkembangan fisik anak sangat mendukung proses pembelajaran. Selain itu juga dengan mengusahakan linkungan fisik kelas yang nyaman siswa akan merasa semangat dalam melakukan kegiatan belajar. Hal ini didukung oleh upaya guru dalam mengembangakan pengelolaan kelas bukan hanya sekedar saat proses pembelajaran saja tertapi guru harus memahapi karakteristik perindividu siswa dan guru harus bertanggug jawab atas pembelajaran baik proses pembimbingan baik dalam kelas maupun di luar kelas. Selain upaya yang guru lakukn dalam proses pembelajaran guru juga harus mengimplementasikan tugasnya dengan baik 
di sekolah dengan memotivasi siswa dan memfasilitasi agar meningkatnya potensi siswa di dalam kelas.

Dengan melalui penjadwalan piket dimana siswa diajarkan dengan kesetiaan kawana, serta mebiasakan siswa untuk bersih dan sehat dalam lingkungan sekolah salah satunya bisa dilakukan dengan cara piket kelas. kegiata piket kelas bisa dilakukan setiap hari ketika pagi hari sebelum pembelajaran dimulai atau siang hari setelah pebelajran selesai. Penerapan penjadwalan piket ini secara tidak langsung dapat bermanfaat antara lain membentuk sikap siswa yang disiplin dan bertanggung jawab. Tugas dan tanggung jawab dalam kegiatan piket kelas antara lain membuang sampah pda tempatnya, menyamu kelas, menyiram bunga serta melakukan pel di dalam kelas. Selama ini di seklah, guru membagikan tugas piket secara perkelompok.

Hal ini sesuai dengan apa yang di katakana oleh (Nugraheni, 2017-28) tugas piket dikelas dilakukan oleh kelompok piket yang bertugas membuat lingkungan tempat belajar. Piket kelas bertujuan untuk membuat lingkungan tempat belajar bersih, rapi, dan nyaman serta membuat kelas indah dipandang. Selain membuat kelas bersih, rapi dan nyaman, piket kelas juga dapat meningkatkan kedipsiplinan, kemandirian dan tanggung jawab. Selain piket kebersihan siswa dituntuk untuk aktif terhadap proses pembelajaran yang dimana dalam satu kelas siswa tentunya memiliki perbedaan baik aspek kecerdasan, psikologis dan biologis. Perbedaan tersebut dapat menimbulkan beragam tingkah lakuh siswa di dalam kelas. sehingga bagaimana cara guru dalam mexspor materi dalam pembelajaran sehinnga tujuan pembelajaran dapat tercapai.

Dalam kegiatan pembelajarn di kelas guru memiliki tugas mendidik dan mengajar siswa. guru sebagai pendidik bertugas membentuk karakter dan memberi manfaat bagi diri siswa sendiri maupun orang lain. Sebagai pengajar guru bertugas mentransfer ilmu pengetahuan untuk anak didiknya agar bisa menjadi orang yang baik. Oleh karenanya guru bukan hanya berperan sebagai pendiddik saja tetapi bagaimana guru menerapkan hukuman yang mendidik ke siswa atau patuh terhadap peraturan yang guru terapkan baik yang dibuat sendiri maupun secara bersama-sama. Dalam hal ini pemberian hukuman kepada siswa akan membuat ia menyesali perbuataanya, pemberian hukuman juga sebagai tindakan yang dijatuhkan kepada anak secara sadar dan sengaja sehingga siswaa tidak akaan mengulangi keslahaan tersebut. Dengan adanya hukuman yang guru berikan ke siswa ia akan menjadi sadar akan perbuatanya dan berjanji tidak akan melakukan kesalahan itu lagi. 
Kemampuan guru dalam melakuakn pembelajaran dalam kelas bukan hanya dapat mengendalikan suasana di dalam kelas saja tetapi juga pemanfaatan media atau alat peraga tentu berdampak positif bagi proses penerapan materi kesiswa. Seorang guru dapat melakuakn pembelajaran dalam kelas berupaya untuk menyediakan alat peraga maupun media yang menarik perhatian bagi siswa sehingga memudahkan siswa untuk memahami materi yang sedang diajarkan. Dalam hal ini guru telah mampu mengusahakan sumber belajar yang berguna bagi proses pembelajaran serta dapat menunjang pencapaian proses belajar mengajar. Berdasarkan media yang digunakan guru diantaranya dengan memanfaatkan lingkungan sekitar kelas, menggunakan media teknologi berupa $L C D$ maupun media yang dibuat oleh siswa.

Hal ini sesuai dengan apa yang dikatakan oleh Agung (Suryani, 2018-4) bahwa media pembelajaran merupakan media yang digunakan dalam pembelajaran, yaitu meliputi alat bantu guru dalam mengajar serta sarana pembawa pesan dari sumber belajar kepenerima pesan belajar yang disebut dengan siswa. Hal ini mengemukakan bahwa ssuatu proses pembelajaran harus ada dukungan dengan menggunakan media pembeljaran agar proses pembelajaran menjadi kondosif.Penggunaan media juga merupakan salah satu alat yang memudahkan guru dalam melakukan menyalurkan pengetahuan. Bukan hanya itu saja dengan memanfaatkan media guru lebih mudah mengatur materi pelajran sehingga penyjian materi pelajaran dapat dilakukan secara sistematik dan lebih teratur. Dengan demikian siswa akan menjaddi antusisa dan betah mengikuti pelajaran, sehingga berdampak positif pada perubahan tingkah laku siswa untuk menghindari timbulnya tingkah laku yang negatif yang dapat menimbulkan terjadinya pelanggaran terhadap aturan yang ditetapkan dalam kelas.

Hasil penelitian menunjukan bahwa wali kelas IV memilik karaktersitik, mampu menggayomi, dan antusia dalam membimbing siswanya dalam proses pembelajaran selain itu juga guru memiliki banya pengetahuan dan lebih cenderung disukai oleh siswa. Hasil penelitiani menunjukan bahwa guru dalam hal ini wali kelas telaah menampilkan tingkah laku yang baik, antusia dalam melakkan proses pembelajaran dengan siswanya. Sehingganya siswa juga tampak tertarik dengan antusias guru dalam mengajar. Hal lain juga yang dilihat dari guru tampak memiliki kedekatan dengan siswa, yang tampak dengan terbukanya guru dalam melakukan proses pembelajaran didalam kelas dengan sering mengajak siswa berinteraksi dan seringkali bergurau di dalaam kelas.

Dalam hal ini guru tentunya harus mengeusai bahan materi pembelajaran agar bisa mengembangkan dalam artian meningkatkan kemampuan dalam hal ilmu yang dimiliki. 
Guru merupakan indiviu yang dituntut agar terampil dalam melakukan kegiatan mengajar, jadi disini guru juga harus paham dengan apa yang mereka ajarkan sehinnganya guru dengan mudah untuk melakukan tujuan pembelajaran. Kegiatan ini merupakan cara guru dalam menilai sejauh mana efektifnya pembelajaran berlangsung di dalam kelas, maka apabila masi terdapat hambatan maupun masalah guru harus melakukan kedipsiplinan sehingga hambatan tersebut tidak akan terulang kembali. Sehingganya guru melakukan aspek penilaina yang dilakukan guru bukan hanya pada aspek pengetahuan saja, akan tetapi juga dilakukan pada aspek sikap dan ketrampilan siswa. Berbagai jenis latihan diberikan guru dimaksudkan agar siswa mampu meningkatkan kemaampuan dan pengetahuan mengenai materi yang diajarkan tersebut, sehingga proses pembelajaran lebih bermakna.

2. Tingkah Laku dalam Kelas

Pendidikan merupakan suatu bentuk terencana dalam mewujudkan suasana belajar dan proses pembelajarn agar siswa secara aktif dapa mengembangakan potensi dirinya. Pada hakekatnya pendiddikan sudah merupakan kebutuhn manusia yang dapat menyediakan lingkungan yang aman sehingga siswa dapat mengembangkan berbagai potensi dalam dirinya.

Guru merupakan orang tua kedua dari anak, tumbuk kembang seorang anak dapat dibentuk sebagian dari sekolah tempat ia belajar sehingganya guru dapat memberikan pengetahuan maupun guru bertingkah laku secara positif dan negatif dapat dilihat siswa dilingkungan sekolah, oleh karenya guru harus berdampak positif kepada siswa sehingga bisa membuat karakteristik siswa yang lebih baik.Guru sebagai manajer dutuntut agar senantiasa memaksimalkan dalam melakukan pengelolaan kelas. Akan tetapi tidak dapat dipungkiri bahwa masih ada beberapa masalah terkait dengan guru itu sendiri. Hal ini merupakan dampak dari tugas guru yang berdimensi banyak diamana selain harus menjadi pengajar, guru juga dituntut untuk melakukan hal lain diluar tugas utamanya.

Tingkah laku peserta didik merupakan suatu hal yang bersifat individu. Mereka menonjolkan sifat yang personal dalam menghadapi kehidupan. Bagaimana seorang peserta didik mengalami paksaan juga bergantung kepada perkembangannya dan juga kepribadiannya, seberapa lama dan intensitas dari paksaan itu juga merupakan sebuah faktor, hilang kepercayaan yang total, perasaan bersalah, malu, takut, dan menarik diri. (Hakim, 2012:82). Dalam proses pembelajaran bukan hanya guru saja yang mengalami terjadinya hambatan dalam melakukan proses pembelajaran. 
Dari hasil penelitian ditemukan beberapa hambatan yang berasal dari siswa, dimana siswa terlihat sering menimbulkan masalah didalam kelas, perilaku yang kurang tertib pada saat proses pembelajaraan dan ada sebagian siswa mengganggu temannya sehigga terjadinya hambatan dalam belajar. Serta melakukan pelangaran pada aturaan yang sudah ditetapkan oleh guru.Tingkah laku siswa merupakan kegiatan yang aktif dilakukan oleh individu baik yang dilihat langsung, maupun yang tidak dilihat langsung. Sedangkan Menurut Skinner seperti yang dikutip oleh Noto Atmodjo perilaku merupakan respon atau reaksi seseorang terhadap stimulus atau rangsangan dari luar. Oleh karena perilaku ini terjadi melalui proses adanya stimulus terhadap organisme, dan kemudian organisme ini merespons (Idhami,2012-65).Fhilip Graham dalam (Okvianti, 2016) perilaku anak dapat dipengaruhi faktor pribadi maupun lingkungan. Seperti pendapat, faktor pribadi yaitu faktor yang terdapat dalam diri seseorang yang merupakan bawaan lahir. Misal faktor bakat yang mempengaruhi temperamen dan ketidak mampuan seseorang dalam menyesuaikan diri.Dalam hal ini guru telah berupaya dalam mensinergikan antara lingkungan fisik maupun lingungan sosio-emosional kelas guna menciptakan iklim kelas yang kondusif, karena pada dasarnya kelas merupakan sarana berinteraksi antara siswa dengan siswa maupun antara siswa dengan guru.

3. Penyelesaian Masalah dalam Kelas

Pendekataan yang sering digunakan guru antara lain pendekatan otoriter, pengajaraan, pengubahaan tingkah laku, sosio-emosional, kerja kelompok, elektis atau pluralistik, maupun teknologi informasi. (a) Pendekatakan otoriter. Didalam proses kegiatan pembelajaran kedisiplinan merupakan hal yang paling diutamakan sehingga dapat menciptakan suasaana belajar yang kodusif. Sehingganya apabila ada siswa yang melakukan pelanggaran yang kesekian kalinya guru akan melakukan tindakan berupa memberikan sangsi yang mendidik dimana sangsi bagi siswa yang melanggar peraturan di dalam kelas biasanya berupa membersikan pot-pot bunga, membersikan WC, memungut sampah, maupun membersihkan lingkungan kelas. Berbagai peraturan tersebut ibaratnya sebagai pengaasa yang wajib untuk ditaati. Oleh sebab itu, disini guru melakukan pendekatan yang baik kepada siswa melalui peraturan ini, dan bukan berdasarkan keinginan sendiri. (b) Pendekatan pengajaran. Guru berupaya membuat perencanaan pembelajaran yang matang dalam proses pembelajaran serta memperhatikan kesesuain antara materi dengan media maupun model yang akan digunakaan dan mempertimbangkan waktu dalam setiap prose pembelajaran. Hal ini dapat diartikan bahwa guru senantiasa menghindari kebiasan mengajar dengan apa adanya, apalagi tanpa 
perencanaan yang matang. Pembelajaran yang dilakukan secara terarah membuat siswa merasa antusias dalam belajar. (c) pendekatan pengubahaan tingkah laku. Dalam hal ini guru memberikan rangsangan terhadap tingkah laku siswa yang baik atau positif harus dengan pujian atau motivasi yang menimbulkan perasaan senang atau gembira. Namun apabila siswa menunjukan tingkah laku yang kurang baik dalam kelas maka guru memberi sangsi atau hukuman yang membuat siswa tidak akan mengulangi hal itu lagi. (d) Pendekatan sosio-emosional. Dalam pendekatan ini siswa didorong untuk bersikap ramah terhadap sesama dengan saling menghargai, menghormati serta guru memaksimalkan peranya didalam kelas dengan bersedia mendengarkan pendapat, saran, gagasan yang diungkapkan oleh siswa, maupun ungkapan masukan dari rekan sesama guru dan orang tua siswa demi mengoptimalkan proses pembelajaran. Dalam Sosioemosional siswa guru telah berupaya dalam mensinergikan antara lingkungan fisik maupun lingungan sosio-emosional kelas guna menciptakan iklim kelas yang kondusif, karena pada dasarnya kelas merupakan sarana berinteraksi antara siswa dengan siswa maupun dengan guru. (e) Pendekatankerja kelompok. Melalui pendekatan ini guru senantiasa melakukan kerja kelompok pada siswa agar proses pembelajaran menjadi efektif dan produktif. Dari hal ini guru membentuk dan mengaktifkan siswa agar mampu bekerja sama dengan tim kelompok mereka dalam artian hal tersbut dilaksanakan agar semua siswa dapat saling bekerjasama dengan teman di dalam kelompoknya dengan baik tanpa adanya hambatan yang terjadi. Kegiatan ini dilakukan guru untuk membuat kelompok belajar di dalam kelas dan menempatkan siswa dengan kemampuan yang sama dalam bidang akademik sebagai tutur sebaya, tutor sebaya membantu teman kelompoknya yang kesulitan memahami materi agar terselesaikan bersama. Dalam hal ini posisi tempat duduk yang disesuaikan degan karakteristik dan kebutuhan masing-masing siswa. (f) Pendekatan teknologi dan informasi. Pada pendekatan ini guru sering menggunakan media pembelajaran teknologi dan informasi yang mendukung proses pembelajaran yang membuat kondisi di dalam kelas tidak terasa jenuh. Dengan memperlihatkan gambar atau video lewat LCD yang membangkitkan semangat belajar siswa. Hal ini bisa membuat keterampilan siswa dalam belajar. (g) Pendekatanelektis atau pluralistik. Penggunaan pendekatan ini dapat dilihat dari cara guru menerapkan kedisiplinan di dalam kelas melalui tindakan guru dalam memadukan pendekatan kekuasan dan pendekataan perubahan tingkah laku. Guru sering menekankan pentingnya menaati setia aturan di dalam kelas dan membuat kesepakatan dengan siswa mengenai sangsi atas pelanggaran terhadap aturan tersebut. 
Pendekatan manajemen kelas yang ada di SDN 20 Dungingi ini tidak hanya terpaku pada satu atau dua pendekatn saja. Guru memiliki kesempatan untuk berkreasi dan bebas dalam menggabungkan ketujuh pendekatan itu sekaligus ketika menghadapi situasi yang mengharuskan menggunakan pendekatan tersebut. Dengan demikian guru lebih bijak dalam menetukan pendekatan apa saja yang akan digunakan untuk menciptakan iklim pembelajaran yang kondusif.

\section{SIMPULAN}

Kesimpulannya adalah bahwa pengendalian tingkah laku siswa dapat diatasi dengan caraguru sebagai motivator dan pemberi nasehat, sebagai pembimbingan, melalui penjadwalan piket, pemberian hukuman yang mendidik, serta penguasaan materi terhadap siswa. Pendekatan yang sering guru gunakan di kelas yaitu pendekatan oteriter, pengajaraan, perubahan tingkah laku, sosio-emosional, kerja kelompok, elektis atau pluralistik, maupun teknologi informasi serta meningkatkan kerja sama antara guru dan orang tua.Meskipun hasil penelitian ini telah membuktikan bahwa usaha guru dalam pengendalian tingkah laku siswa guru diharapkan bisa terus menciptakan suasana yang kondusif dalam menggunakan pendekatan manajemen kelas dalam pembelajaran. Diharapkan juga kepada siswa supaya lebih menaati setiap aturan yang berlaku di dalam kelas dan lebih memelihara situasi kelas yang konduktif. Selalu menciptakan komunikasi yang baik antara pihak sekolah maupun orang tua siswa, sehingganya bisa menciptakan program yang diharapkan di sekolah.

\section{REFERENSI}

Azzet, A.M. 2011. Menjadi Guru Favorit: Jogjakarta: Ar-Ruzz Media

Hakim, L. 2012. Internalisasi Nilai-Nilai Agama Islam Dalam Pembentukan Sikap Perilaku Siswa SD Islam Terpadu Al-Muhtaakin. Tasik Malaya

Handayani, S. 2017 Skripsi Upaya Guru Menangani Perilaku Kenakalan Siswa Di SD Muhammadiyah 1 Surakarta Tahun Ajaraan 2016/2017. Fakultas ilmu Pendidikan Universitas Muhammadiyah Surakarta

Idhami, D.E. 2012. Psikologi Perkembangan Peserta didik: PT Remaja Rosdakarya

Karwati, E. dan Priansa, D. J. 2014. Manajemen Kelas: Guru Profesional yang Inspiratif, Kreatif, Menyenangkan, dan Berprestasi. Bandung: Alfabeta

Mubarrok, H. 2017. Ketika Guru dan Siswa Saling Bercermin (Kajiaan Refleksi Diri Membangun Motivasi Menju Perbaikan Diri). Jakarta: Elex Media Komputindo 
Nugraheni, S 2017. Jurnal Penguatan Pendidikan Karakter FKIP, UMP Uniersitas Muhamadia Puworkerto

Okavianti, E. 2016. Skripsi Studi Kasus Perilku Menyimpang Siswa Kelas 1 SD Negeri Ngemplak Nganti Sleman.FIP Universitas Negeri Yokyakarta.

Suryani N dan Putria, A. 2018. Media Pembelajaran Inovatif dan Pengembangannya. Bandung: PT Remaja Rosdakarya

Suwardi dan Daryanto. 2017. Manajemen Peserta Didik. Yoyakarta: Gava Media Usman, M. U.2011. Menjadi Guru Profesional. Bandung: Pt Remaja Rosdakarya 